\title{
Standpunt
}

\section{Standpunt oor kernenergie in Suid-Afrika}

\author{
Dr. Wessel Van Zyl de Villiers \& Dr. Eben Mulder
}

\section{AGTERGROND}

Daar is in die onlangse verlede by verskeie geleenthede verwys na die feit dat die groeiende aanvraag na elektrisiteit in SuidAfrika binne enkele jare die aanbod sal oorskry. Om dié rede het Eskom begin om steenkoolkragstasies wat jare gelede in 'n rustoestand geplaas is, voor te berei vir herinbedryfstelling binne 'n paar jaar. Die Departement van Minerale en Energie het ook aangedui dat die mark vir elektrisiteitsverskaffing aan die privaat sektor oopgestel gaan word.

Dit is bekend dat elektrisiteitskoste in Suid-Afrika van die laagste ter wêreld is, iets wat verkieslik behou moet word om die broodnodige ekonomiese groei te ondersteun en beleggings na die land te lok. Verreweg die meeste elektrisiteit in Suid-Afrika word uit steenkool ontwikkel, met die gepaardgaande probleme van lugbesoedeling en groot hoeveelhede as wat geproduseer word. In die lig van bogenoemde is dit belangrik dat alle moontlike bronne van elektrisiteit oorweeg sal word. Trouens, die beleid van die regering is dat daar gestreef moet word na 'n energiemengsel waarin verskeie faktore soos diversiteit van verskaffing, koste, omgewingsimpak en volhoubaarheid in ag geneem is.

In hierdie standpunt word voorgestel dat kernenergie ernstig oorweeg word as 'n betroubare, ekonomiese en veilige komponent van toekomstige elektrisiteitsverskaffing in Suid-Afrika.

\section{DIE INTERNASIONALE STAND VAN KERNENERGIE}

Sestien persent van die wêreld se elektrisiteitsbehoeftes word tans deur sowat 440 kernkragstasies voorsien, en 'n verdere 30 reaktore is in aanbou. Oor die afgelope paar jaar was daar 'n merkbare oplewing in politieke en openbare steun vir kernenergie, onder andere in die VSA en die Skandinawiese lande wat tradisioneel sterk daarteen gekant was. Die meeste Asiatiese lande het reeds vir die afgelope dekade of meer aktiewe programme om die rol van kernkrag in hul ekonomieë te versterk. Die Kioto-protokol en stygende kommer oor aardverwarming het ook belangstelling in kernenergie, as 'n energiebron wat baie min kweekhuisgasse vrystel, verhoog.

Twee groot internasionale inisiatiewe wat spesifiek gerig is op die volgende geslag kernkragreaktore (die sogenaamde vierdegenerasie-reaktore) het in die afgelope vyf jaar beslag gekry. Dit is die International Project on Innovative Nuclear Reactors and Fuel Cycles (kortweg bekend as INPRO) van die Internasionale Atoomenergie-agentskap, en die Generation IV International Forum (GIF) wat deur die Amerikaanse Departement van Energie geloods is. Albei programme ondersoek reaktorkonsepte wat moontlik kan voldoen aan toekomstige vereistes soos ekonomiese mededingendheid, lae omgewingsimpak, minimum kernafval, verhoogde veiligheid en bestandheid teen die proliferasie van kernmateriaal. Suid-Afrika is 'n lid van albei programme.

\section{KERNENERGIE IN SUID-AFRIKA}

Die twee 930 MWe-eenhede van die Koeberg-kernkragstasie het reeds meer as 20 jaar van betroubare verskaffing aan die elektrisiteitsnetwerk agter die rug en lewer tans sowat $6 \%$ van Suid-Afrika se elektrisiteit. In die middel negentigerjare het Eskom begin met 'n doenlikheidstudie na die modulêre korrelbedreaktor (MKBR), 'n projek wat later uitgebrei is in samewerking met plaaslike en internasionale vennote. Die reaktor is gebaseer op tegnologie wat reeds in die 1960's in Duitsland gedemonstreer is.

'n Omvattende tegniese en ekonomiese doenlikheidstudie is sedertdien uitgevoer, asook omgewingsimpakstudies wat wye openbare deelname ingesluit het. Dit is egter steeds nodig dat daar krities gekyk word na die MKBR se voldoening aan die vereistes wat deur besluitnemers, die publiek en internasionale programme soos INPRO en GIF gestel word.

\section{Is die MKBR veilig?}

- Die kragdigtheid van die MKBR, wat meer as 10 maal laer as dié van tipiese ligtewaterreaktore is, maak dit fisies onmoontlik om 'n kernsmelting ("core meltdown") te kry of dit selfs te induseer. Tydens meer as 20 jaar se ontwikkeling in Duitsland is eksperimentele bewys gelewer dat dit onmoontlik is om temperature te bereik wat tot skade aan die brandstof kan lei.

- Die negatiewe temperatuurreaktiwiteitskoëffisiënt van die MKBR maak dit onmoontlik dat die reaktor buite beheer kan raak in die geval van 'n verlies aan koelmiddel (helium). Die inherente aard van die kernklowingsreaksies in 'n reaktor van hierdie tipe lei daartoe dat oormatige temperatuurstygings nie kan voorkom nie en dat die reaktor homself in wese sal afskakel.

- In druk- en kookwaterreaktore is dit nodig om 'n volle brandstoflading aan die begin van 'n bedryfsiklus in die reaktorhart te plaas. Hierdie eienskap van hoë aanvangsreaktiwiteit is uitgeskakel in die MKBR-ontwerp deurdat brandstof (in die vorm van sfere so groot soos snoekerballe) tydens bedryf op ' $n$ kontinue basis gelaai en ontlaai word na gelang van die heersende reaktiwiteitstatus.

- Die strukturele en kernmateriale van die MKBR bestaan hoofsaaklik uit grafiet, met ' $n$ totale massa van ongeveer 750 ton. Dit gee aanleiding tot 'n groot termiese traagheid wat temperatuurskommelings demp. Die uitleg van die brandstofsone is ook sodanig dat geproduseerde na-hitte passief (d.w.s. sonder operateursingryping) deur en vanaf die staaldrukvatoppervlak verwyder sal word.

- Benewens bogenoemde faktore is daar ook tydens die ontwerp van die MKBR seker gemaak dat die reaktor sal voldoen aan al die veiligheidsvereistes wat van toepassing sal wees op vierdegenerasie-reaktore. 


\section{Is die MKBR ekonomies lewensvatbaar?}

- Beleggers in die MKBR-projek het 'n omvattende reeks ingenieurs- en ekonomiese doenlikheidstudies laat voltooi deur vooraanstaande internasionale organisasies wat McKinsey \& Company en PricewaterhouseCoopers ingesluit het. Die finale verslae deur hierdie maatskappye het afdoende bewys gelewer dat die tegniese en besigheidsplanne van die MKBR-maatskappy 'n puik besigheidsgeleentheid bied, soos ook gedemonstreer word deur die volgehoue steun van beleggers.

- Daar word voorsien dat die meeste komponente van die totale MKBR-aanleg potensieel in Suid-Afrika vervaardig sal kan word. Dit is die uitgesproke wens van die Suid-Afrikaanse beleggers, wat tans verreweg die meerderheid uitmaak, dat tegnologie-oordrag t.o.v. kritieke komponente wat aanvanklik in die buiteland vervaardig sal word, mettertyd na SA sal plaasvind. 'n Suksesvolle MKBR-vervaardigingsbedryf sal duisende werksgeleenthede bied aan mense van oor die totale spektrum van geskooldheid.

- In ooreenstemming met die groeiende internasionale belangstelling in waterstof as brandstof van die toekoms kan die MKBR eweneens 'n belangrike rol speel deur die verskaffing van tegnologieë wat berus op elektrolitiese prosesse (vir die vervaardiging van waterstof) asook elektrotermiese prosesse (vir die verskaffing van hitte, ook vir petrochemiese prosesse). 'n Ander gebied wat groot belangstelling geniet is die benutting van sg. weggooihitte in die termiese siklus vir die ontsouting van seewater in gebiede met 'n tekort aan vars water.

\section{Wat van die kernafval?}

- Soos reeds voorheen aangedui, word die MKBR deurlopend tydens bedryf met brandstof gelaai. Gebruikte brandstof sal in geskikte houers in ' $n$ afgeskermde omgewing binne-in die reaktorgebou ontlaai word. Voldoende kapasiteit word geskep om die gebruikte brandstof op te berg tydens die bedryf van die reaktor asook vir 'n tydperk van 40 jaar of langer nadat die reaktor afgeskakel is. Die besluit rakende die finale verwerking, opberging of wegdoening van die kernafval kan dan geneem word op grond van die mees moderne tegnologie wat op daardie stadium beskikbaar is. Wat Suid-Afrika betref, is die Departement van Minerale en Energie tans besig om 'n nasionale strategie en beleid vir kernafval te finaliseer.

- Wat die ontwerp van MKBR-brandstof so uniek maak, is dat dit reeds dien as ideale verpakking vir die toekomstige kernafval in dié opsig dat baie klein kerne uraanoksied (0,5 mm deursnee) met ondeurdringbare lagies bedek word wat as inperking van klowingsprodukte tydens en na bestraling dien. Hierdie bedekte partikels word dan in grafietsfere saamgepers, waardeur' $n$ tweede sperlaag gevorm word. Al hierdie versperrings dien ook as uitstekende beskerming teen moontlike uitloging van radioisotope in die hipotetiese geval van waterindringing in die afvalopberg- of wegdoenfasiliteit.

- Die ontwerpe van die reaktor, die brandstof asook die brandstofhanteringstelsel maak die MKBR uiters onaantreklik vir die moontlike proliferasie van kernmateriaal, 'n aspek wat die laaste paar jaar hoë prominensie op internasionale vlak geniet.

- Ondertussen sal navorsing en ontwikkeling voortgaan om die hoeveelheid kernafval, wat reeds laag is relatief tot die afval wat deur ander bronne van elektrisiteit gegenereer word, verder te verminder en om die veiligheid daarvan nog te verbeter.

\section{SAMEVATTING}

Die SA Akademie vir Wetenskap en Kuns doen 'n beroep op alle partye met ' $n$ belang in energieverskaffing, omgewingsbeskerming, ekonomiese groei en sosiale ontwikkeling in SuidAfrika om debatte oor die toekomstige verskaffing van elektrisiteit te voer op grond van wetenskaplike feite en ekonomiese werklikhede eerder as emosie.

NOTA: Ons is tans besig met die voorbereiding van 'n volledige artikel omtrent die rol van die Korrelbed Modulêre Reaktor (KBMR) in Suid-Afrika. Hou ons volgende uitgawes dop. 